Article

\title{
Giant Quartz Veins of the Bundelkhand Craton, Indian Shield: New Geological Data and U-Th-Pb Age
}

\author{
Alexander I. Slabunov ${ }^{1}(\mathbb{D})$ and Vinod K. Singh ${ }^{2, *}$ (i) \\ 1 Karelian Research Centre RAS, Institute of Geology, 185910 Petrozavodsk, Russia; slabunov@krc.karelia.ru \\ 2 Department of Geology, Bundelkhand University, Jhansi 284128, India \\ * Correspondence: vinodksingh@bujhansi.ac.in
}

Citation: Slabunov, A.I.; Singh, V.K Giant Quartz Veins of the Bundelkhand Craton, Indian Shield: New Geological Data and U-Th-Pb Age. Minerals 2022, 12, 168 https://doi.org/10.3390/ $\min 12020168$

Academic Editor: Simon Paul Johnson

Received: 21 December 2021

Accepted: 24 January 2022

Published: 28 January 2022

Publisher's Note: MDPI stays neutral with regard to jurisdictional claims in published maps and institutional affiliations.

Copyright: () 2022 by the authors Licensee MDPI, Basel, Switzerland. This article is an open access article distributed under the terms and conditions of the Creative Commons Attribution (CC BY) license (https:// creativecommons.org/licenses/by/ $4.0 /)$.

\begin{abstract}
Giant quartz veins are widespread on the Bundelkhand Craton of the Indian Shield which precise ages with a SHRIMP-II, U-Th-Pb isotope are quantified in this article. Their relative geological age is well-documented: they cut the Paleoproterozoic (2150-1800 Ma) sediments of the Bijawar Group and are overlain by Proterozoic (1670-1030 Ma) sediments at the base of the Upper Vindhyan Supergroup. U-Th- $\mathrm{Pb}$ dating of zircon grains from a quartz vein was carried out to assess major event of their formation as $1866 \pm 12 \mathrm{Ma}$. This data is consistent with the relative geological age of the veins. In addition, the quartz veins were shown to contain 2.86, 2.7, and 2.54 Ga xenocrystic zircon grains. Rocks with these ages are abundant in the craton. The formation of a giant quartz vein swarm is associated with the deformation of the Bundelkhand Craton lithosphere during 1.9-1.8 Ga ago triggered by compression caused by collision processes at the western flank of the Columbia Supercontinent on one side and plume activity on the other.
\end{abstract}

Keywords: quartz vein; zircon; Proterozoic; Bundelkhand Craton

\section{Introduction}

Quartz veins are widespread around the world. They are essential indicators of the stressed state and hydrothermal activity of the earth's crust during their formation [1]. They are studied to recognize episodes in the earth's crust evolution characterized by intense deformations associated with hydrothermal activity and often with ore formation. Therefore, it is important to determine the timing of such episodes. Giant quartz veins on the Bundelkhand Craton of the Indian Shield are abundant [2,3] (Figure 1). The biggest veins have largely shaped the region's landscape. They are up to $200 \mathrm{~m}$ in thickness and can be traced over tens of kilometers (Figure 2a,b). The petrography, petrogeochemistry, and metallogeny of the veins have been studied in detail [2,4,5]. However, their geological relationship with surrounding complexes (granitoids, greenstones, dikes, and sediments) and the timing of their formation remains the subject of discussion.

The present contribution aims to report new data on the geological relationship of the quartz veins with the Proterozoic complexes of the Bijawar Group and the Vindhyan Supergroup and the results of $\mathrm{U}-\mathrm{Th}-\mathrm{Pb}$ dating of zircon grains from one of these veins cutting an Archean granite-greenstone complex in the Central Bundelkhand terrain of the craton. 


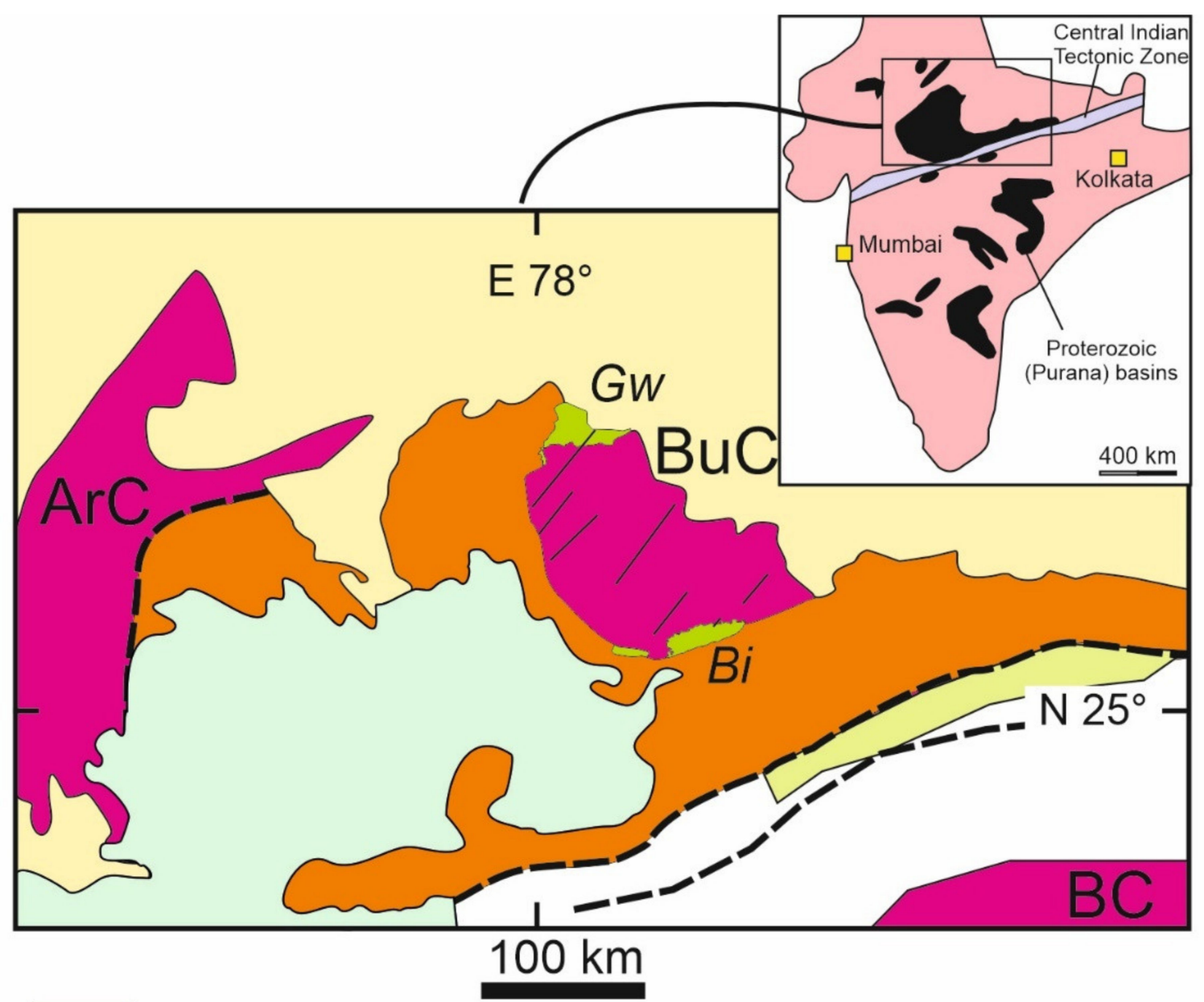

Alluvium cover

Satpura Mobile Belt
Deccan Trap

Fault

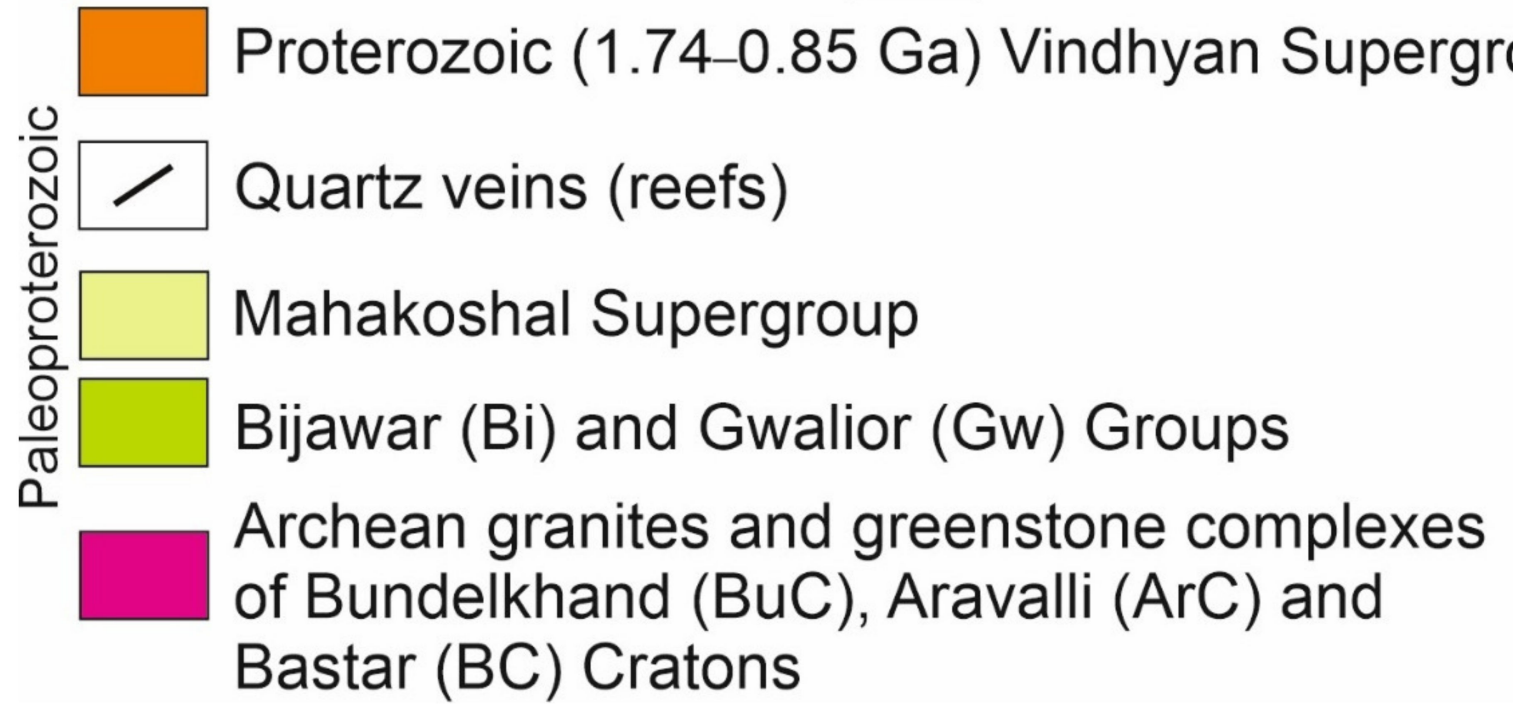

Figure 1. Scheme showing the geological structure of the northern Indian Shield and the location of the giant quartz veins (after [3,6] and the authors' original data). Inset map shows the Indian Shield with Proterozoic basins. 

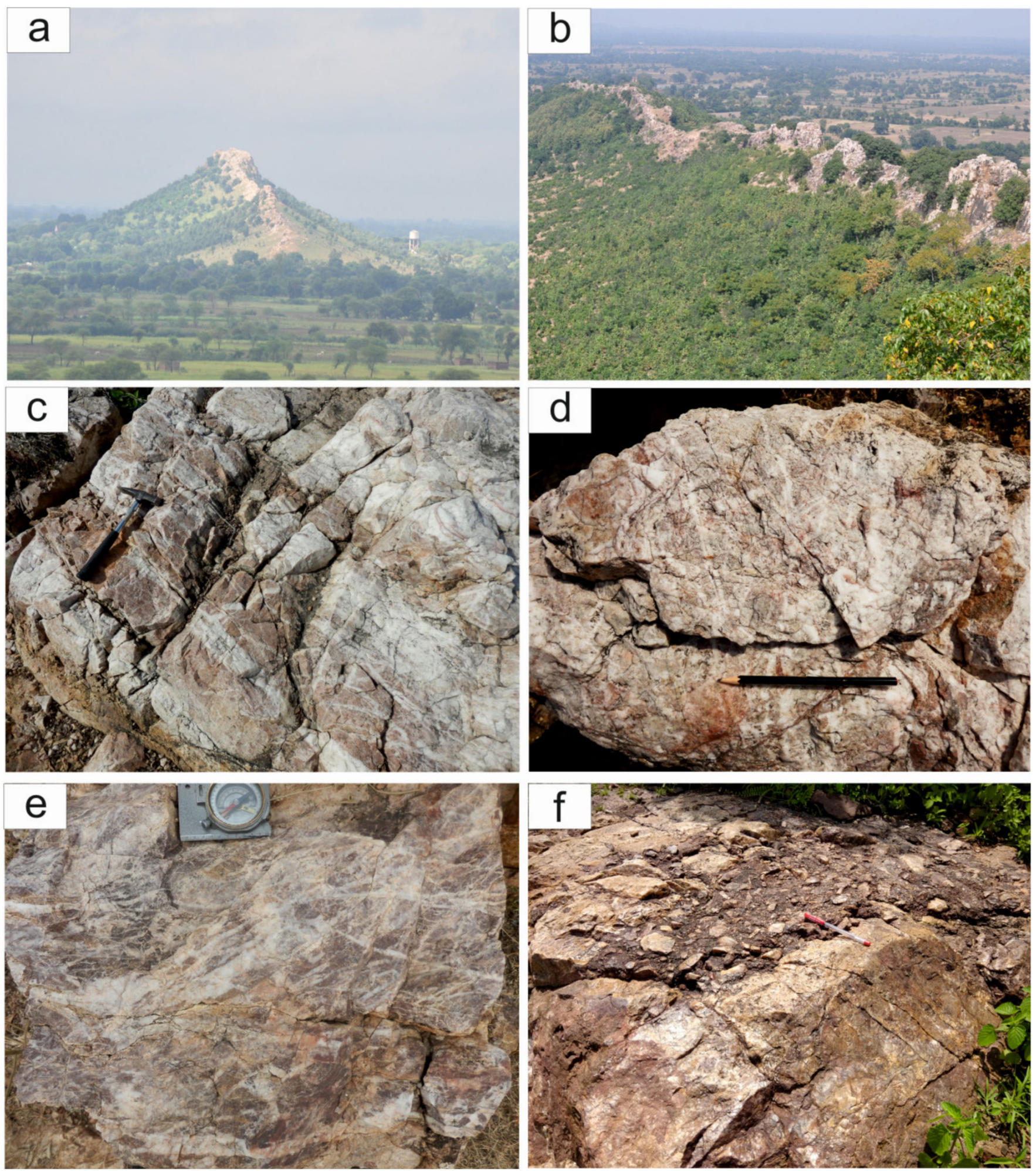

Figure 2. Giant quartz veins in the Bundelkhand Craton: (a) near Babina (profile view); (b) near Bijawar NW-SE (see Figure 3); (c) sample BA15-2/2 (reddish-milky quartz) was taken from this quartz vein; $(\mathbf{d}, \mathbf{e})$ showing field exposure of the quartz veins in central Bundelkhand region; and (f) breccia with veined quartz fragments of the Vindhyan Supergroup occurring on the quartz vein $\left(24^{\circ} 53^{\prime} 02.27^{\prime \prime} \mathrm{N}\right.$ and $\left.78^{\circ} 04^{\prime} 08.34^{\prime \prime} \mathrm{E}\right)$; the pen with red cap is on contact of a quartz vein and breccia directly. 


\section{Geology of the Bundelkhand Craton and Surrounding Proterozoic Basins}

Lying in the northern Indian Shield, north of the Satpura tectonic zone, are the Bundelkhand and Aravalli cratons (Figure 1). The Archean complexes of the Bundelkhand Craton are unconformably overlain by Proterozoic sedimentary complexes [3,6,7]. The Archean complexes consist largely of Neoarchean K-granites, but Paleoarchean grey gneisses (after TTG granitoids) and amphibolites, Meso-Neoarchean greenstone complexes, Mesoarchean layered intrusions, Neoarchean TTG and sanukitoids occur in the craton as well [5,8-24]. The Archean rocks have been metamorphosed in Archean time, mainly under amphibolitefacies conditions, but relics of eclogite facies occur as well [25-28]. The Archean complexes are cut by three different-aged (ca. 2.1-2.0, 1.99, and 1.1 Ga) gabbroic dikes [29,30] and Paleoproterozoic giant quartz veins. The timing of three major events for quartz veins formation is imprecisely estimated by the K-Ar method at 2010-1930 Ma, 1850-1790 Ma, and 1660-1480 Ma [4,7]. The hydrothermal stage of quartz veins formations was estimated as 1.9-2.0 Ga ago [2,5]. The formation temperature of the quartz veins from fluid inclusion studies is estimated at $150-250{ }^{\circ} \mathrm{C}$ [5]. The condition for a Paleoproterozoic metamorphic event is also estimated at $\mathrm{T}=150-250^{\circ} \mathrm{C}$ and $\mathrm{P}=3-5 \mathrm{kbar}$ which is consistent with prehnite-pumpellyite facies [28]. Thus, this metamorphism should be associated with late hydrothermal processes of quartz veins in the Bundelkhand Craton.

Bundelkhand Craton rocks are unconformably overlain by the Paleoproterozoic (2.2-1.8 Ga) sediments of the Bijawar and Gwalior groups and by the Paleo-Neoproterozoic $(1.75-0.85 \mathrm{Ga})$ sediments of the Vindhyan Supergroup (Figure 1). The sedimentary complexes of the Bijawar and Gwalior groups are exposed along the southern and northern flanks of the craton, and Vindhyan Supergroup rocks rest on the craton on the west and south; its small relics occur near Dhala village west of Babina in the craton [22] (Figure 3).

The Paleoproterozoic Gwalior rift-related basin, located at the northern flank of the craton, is made up of Gwalior Group rocks (Figure 1). The volcanic-sedimentary Gwalior Group is divided into two units: the Par Formation (older) and the Morar Formation (younger) [31]. The lower unit consists of conglomerates and sandstones and the upper unit is composed of limestone, iron formation, and volcaniclastic sediments with mafic sills (Figure 3). Par Formation sediments contain fragmental zircon grains dated at 3600-2495 Ma (2500-2600 Ma zircon grains are most common), and those in the upper portion of the sequence (Morar Formation) carry 3100-1870 Ma zircon grains [32]. The mafic sills in the upper unit are dated (mineral-whole-rock Sm-Nd isochron) at $2104 \pm 23 \mathrm{Ma}$ [33]. The age of these basic rocks is estimated from Rb-Sr and K-Ar data at 1775-1790 Ma [3]. Thus, the lower unit of the Gwalior Group is dated at 2.4-2.1 Ga and the upper unit at 2.1-1.8 Ga.

The Paleoproterozoic Bijawar basin, composed of Bijawar Group rocks, is located at the southern flank of the Bundelkhand Craton [3]. Its 4-20 km wide exposures are traced for about $100 \mathrm{~km}$ along the southern flank of the craton. Bijawar Group rock rest with angular unconformity on Bundelkhand granites and are overlain with angular unconformity by Vindhyan Supergroup sediments (Figure 3).

The rock sequence of the Bijawar Group, like that of the Gwalior Group, falls into two subgroups [31]. The base of the lower Moli Subgroup is formed of basal quartz conglomerates; these are overlain by basalt lava, cherts, and dolomite sandstones with stromatolites. This unit contains uranium mineralization zones. The upper Gangau Subgroup consists of phosphorites and ferruginous sandstones. They seem to have formed in a shallow-water environment, near the shoreline of a rift-related basin [3]. Lying between the above subgroups is the Dargawan mafic sill. The isotope ( $\mathrm{Rb}-\mathrm{Sr}$ isochron method) age of this intrusion is $1967 \pm 140 \mathrm{Ma}$ [30], although its age was estimated earlier at $1789 \pm 71 \mathrm{Ma}$ [3] and Kurat lava is $1691 \pm 180 \mathrm{Ma}$ [3]. Sediments at the base of the sequence (Moli Subgroup) were shown to contain clastic zircon grains dated at 3200-2160 Ma (2500 Ma zircon grains are most common) [32]. These data suggest that the lower unit sediments of the Bijawar Group are 2150-2000 Ma old. The upper portion of this sequence (Gangau Subgroup) seems to 
be $2000-1800$ Ma old, considering the age of the upper Gwalior Group, with which it is correlated [3,32].

Compositionally, the intrusive and volcanogenic rocks of the Paleoproterozoic basins are classified as low-P, low-Ti, high-LILE, high-LREE continental tholeiitic basalts and andesite-basalts. The lava seems to have been produced by mantle plumes as a result of the partial melting of a depleted mantle source followed by crustal matter contamination $[3,33,34]$.

The Vindhyan Supergroup (1.74 to $0.85 \mathrm{Ga}$ ) rests unconformably on both Archean rocks and the Paleoproterozoic sediments of the Bijawar/Gwalior Group [35]. It is subdivided into Lower (Semri Group) and Upper (Kaimur, Rewa, Bhander Groups) Vindhyan. The contact between these units is marked locally by conglomerates (e.g., Pipartola) and unconformity [3]. The Lower Vindhyan has been dated thoroughly at 1738-1350 Ma. These conclusions are mainly based on the following evidence: the detrital zircon age from sandstones at the base of the sequence is 1738-3300 Ma [32]; the Pb-Pb age of the overlying Kajrahat limestone is $1729 \pm 110 \mathrm{Ma}$ [36], zircon grains from the overlying volcaniclastic Porcellanite Formation are dated at 1628 \pm 8, 1640-1630 and 1700-1600 Ma [32,37-39] and those from Rampur Shale tuffs at $1602 \pm 8,1593 \pm 12 \mathrm{Ma}$ [37]; the Pb-Pb age of Rohtasgarh Limestone from the upper Semri Group is $1599 \pm 48 \mathrm{Ma}$ [36]; and detrital zircon from overlying sandstones is 1341-3300 Ma old [32].

The age of a detrital zircon population from the Pipartola Conglomerate (basal Kaimur Group) varies from $1670 \mathrm{Ma}$ to $3.3 \mathrm{Ga}$ with peaks at 1.8-1.9 and 2.5-2.6 Ga [32]. The age of Kaimur Group sandstone-shales (basal Upper Vindhyan), estimated with regard to the above data, is 1670-1030 Ma [32]. This date is consistent because they are cut by $1074 \pm 14$ Ma Majhgawan kimberlite [40]. The upper age of the Upper Vindhyan, based on the $\mathrm{Pb}-\mathrm{Pb}$ dating of Bhander Limestone, is $866 \pm 90 \mathrm{Ma}$ [36].

\section{Methods}

To study the geological relationship of quartz veins with surrounding rocks, a detailed geological mapping method was used to trace vein contacts along strike. This work was done near Bijawar and to the west of Lalitpur. Besides, Google Earth satellite images (https: / / earth.google.com/web /@21.18665933,77.59897369,362.62522031a,2977943. $64498407 \mathrm{~d}, 35 \mathrm{y},-0 \mathrm{~h}, 0 \mathrm{t}, 0 \mathrm{r}$ ) were accessed on 11 April 2018 and used for drawing a structural scheme of a quartz veins swarm of the Bundelkhand Craton (Figure 3). For this purpose, satellite images of the entire area were deciphered and lineaments with the characteristics of quartz veins were identified. Interpreting the lineaments as part of these structures was controlled using geological information on the key areas where the authors conducted special studies, e.g., Babina and Bijawar (Figure 3) or which have been described in detail in the literature [2]. It should be noted that the positive results of the use of remote methods for the structural study of quartz veins in the craton have been reported earlier [2].

A sample for geochronological studies was taken from a natural outcrop. Zircon grains were separated from ca. $1 \mathrm{~kg}$ sample in the Analytical Laboratory of the Institute of Geology, KarRC, RAS, Petrozavodsk, Russia using heavy liquids.

The geochronological study of the zircon grains was conducted on a SHRIMP-II ion microprobe at the VSEGEI Centre for Isotope Studies, St. Petersburg, Russia using standard procedures [41,42]. Zircon grains placed together with standard zircon 91500 [43] and Temora [44] into the epoxy matrix, were polished to about the grain center and coated with $\sim 100$ Å thick $99.999 \%$ gold layer. The results obtained were processed using SQUID v1.12 and ISOPLOT/Ex 3.22 programs [45] and decay constants [46]. Correction for the nonradiogenic lead was made according to the model [47] using a measured ${ }^{204} \mathrm{~Pb} /{ }^{206} \mathrm{~Pb}$ ratio. 


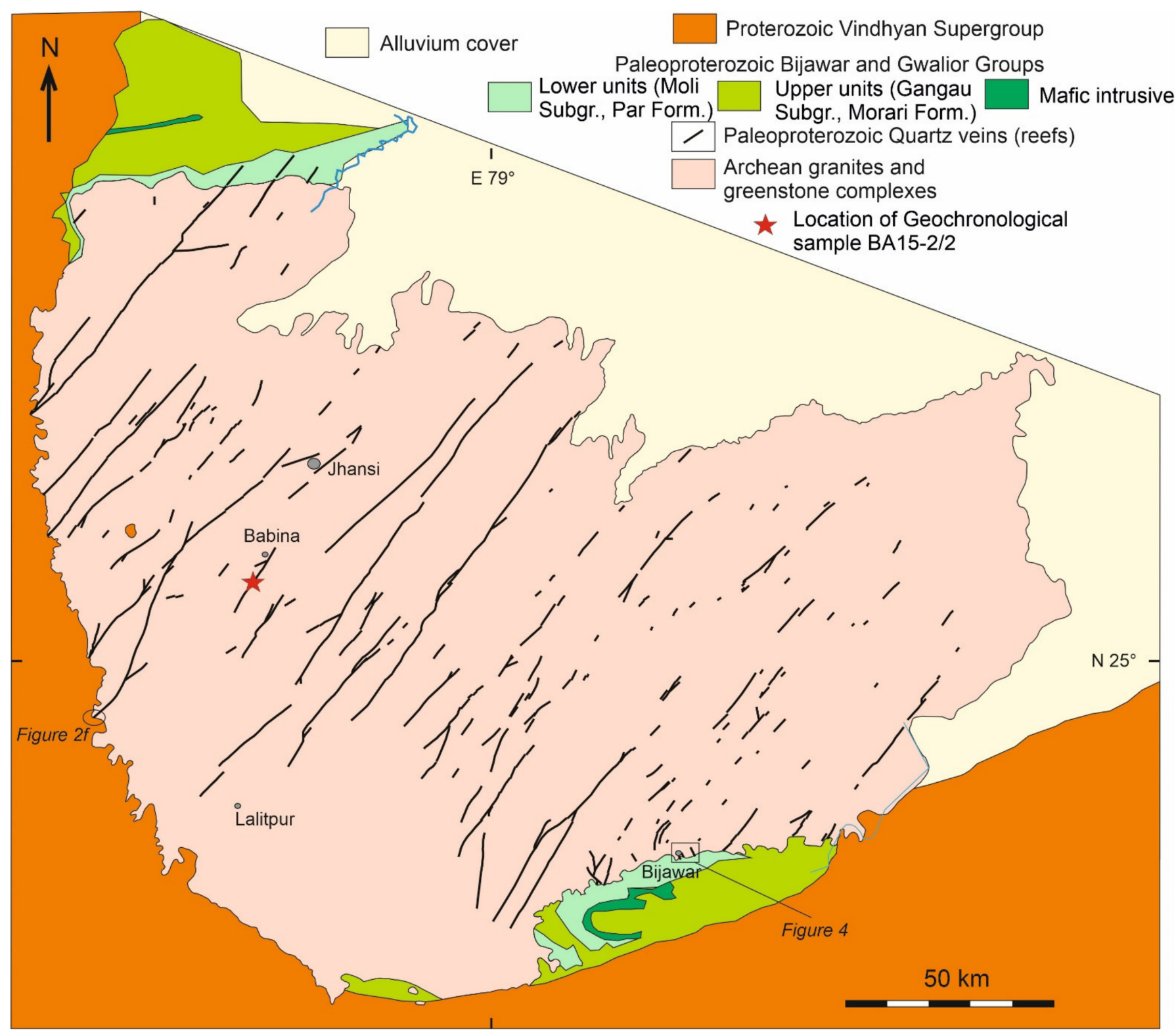

Figure 3. Geological map of a swarm of giant quartz veins in the Bundelkhand Craton. Based on the results of the deciphering of satellite images [48], modified using the authors' original data.

The chemical composition of micron-sized inclusions in zircon grains and the internal structure of the zircon grains were studied on a VEGA II LSH scanning electron microscope with an INCA Energy 350 energy dispersion analyzer in the Institute of Geology, KarRC, RAS, Petrozavodsk, Russia. The internal structure of the zircon grains was also studied in cathodoluminescence in the Centre for Isotope Studies, VSEGEI, St. Petersburg, Russia.

\section{Geology of Quartz Veins}

The quartz vein swarm of the Bundelkhand Craton consists of about 200 veins (Figure 3). The vein length size varies from a few meters to $60 \mathrm{~km}$, and the vein thickness ranges from a few centimeters to $100 \mathrm{~m}$ (Figure 2). Some of the quartz veins have a complex morphology. These display S- and Z-shaped curvatures and often exhibit apophyses and satellite veins. The quartz veins are localized mainly within an NW-SE -trending linear zone $60-70 \mathrm{~km}$ wide in the central part of the craton and are very scarce in other parts (Figure 3 ). Within this zone, the veins are steep and strike mainly $25-55^{\circ} \mathrm{NE}$, but some trend $330-336^{\circ} \mathrm{NW}$ (Figure 3 ). These vein orientations suggest that the veins were formed in 
a stress field with an approximately $\mathrm{N}-\mathrm{S}$ trending compression axis and an approximately $\mathrm{E}-\mathrm{W}$ trending extension axis. Because one strike of the veins is dominant and the other is subordinate, we suppose that two systems of cracks that controlled the vein orientations could have been formed in the simple shear regime.

The quartz veins display two kinds of structure: early formed vein matrix consists of non-transparent (milky, pink, yellow) massive quartz (Figure 2c), and late generated vein is made up of abundant semi-transparent veins (Figure 2d,e), which are purer than the early formed veins. The quartz veins formations during Proterozoic in the Bundelkhand Craton are very similar in structure to Permian-Triassic quartz veins which are associated with the Pfahl shear zone of Bohemian Massif (Germany) [49]. These quartz veins have a multi-phase structure [49].

The veins consist dominantly of quartz. The veins that form early in the process are fine-grained quartz aggregates, whereas the veins that form later are coarser aggregates. Microcline, pyrophyllite, rutile, muscovite, and zircon are present as accessories. The veins host pyrophyllite-diaspore and $\mathrm{Pb}-\mathrm{Zn}-\mathrm{Cu}$ ore nests [2]. The $\mathrm{SiO}_{2}$ content of an early formed quartz vein is $94.70 \%$, while it is $98.60 \%$ in a late generation [2].

Geological mapping conducted in the Bijawar area has shown that quartz veins form an orthogonal system of NW-SE, and NE-SW -oriented veins (Figure 4). The veins cut both Archean K-granites and sedimentary rocks (sandstone and brecciated chert) of the Moli Subgroup of the Bijawar Group (Figure 4). A $~ 2 \mathrm{~m}$ thick vein was traced along strike (strike azimuth $160^{\circ}$ ), its NW portion cuts granites; farther SE, it cuts a granite-quartzite contact and still farther quartzites (Figure 4, inset). This small vein seems to be the apophysis of a bigger NE-SW-oriented quartz vein, which cuts sedimentary rocks. Two kilometers east of the small vein is a giant NW-SE-trending vein, up to $250 \mathrm{~m}$ thick, which can be traced continuously for $2.5 \mathrm{~km}$ along strike. Its greater portion cuts granites, but its southeastern portion cuts sandstone and brecciated chert. Thus, the quartz vein system, which is part of the above swarm, displays cross-cutting contacts with both Neoarchean K-granites and Paleoproterozoic sediments at the base of the Bijawar Group. Hence, they were derived after the formation of the lower Bijawar Group. This conclusion is supported by fragments (xenoliths) of quartz sandstone found in a giant quartz vein near Bijawar (Figure 4).

However, the quartz veins were exposed to direct contact with the Vindhyan Supergroup sandstone-shale in the northwest region of Lalitpur (Figures $2 \mathrm{f}$ and 3 ). In the western part of the craton, where its rocks are unconformably overlain by Kaimur Group sediments (base of Upper Vindhyan) [35], is an outcrop in which a quartz vein is overlain by breccia with veined quartz fragments. Thus, the quartz veins were exposed for the formation of the base of Kaimur Group sediments. Hence, the upper age boundary of the quartz veins is older than the Kaimur Group of the Upper Vindhyan.

The geological and petrographic evidence indicates that: (1) the relationship of the quartz veins with Bijawar Group and Vindhyan Supergroup sediments suggests that their relative geological age is younger than that of the Bijawar Group (i.e., younger than 2150-1850 Ma) and older than that of the Kaimur Group of the Upper Vindhyan (i.e., older than 1670-1030 Ma); and (2) the formation of the quartz veins proceeded in two-stage: pink, fine-grained spent grain or grey varieties form in early-stage of formation and white or semi-transparent coarser-grained varieties in later stage. 


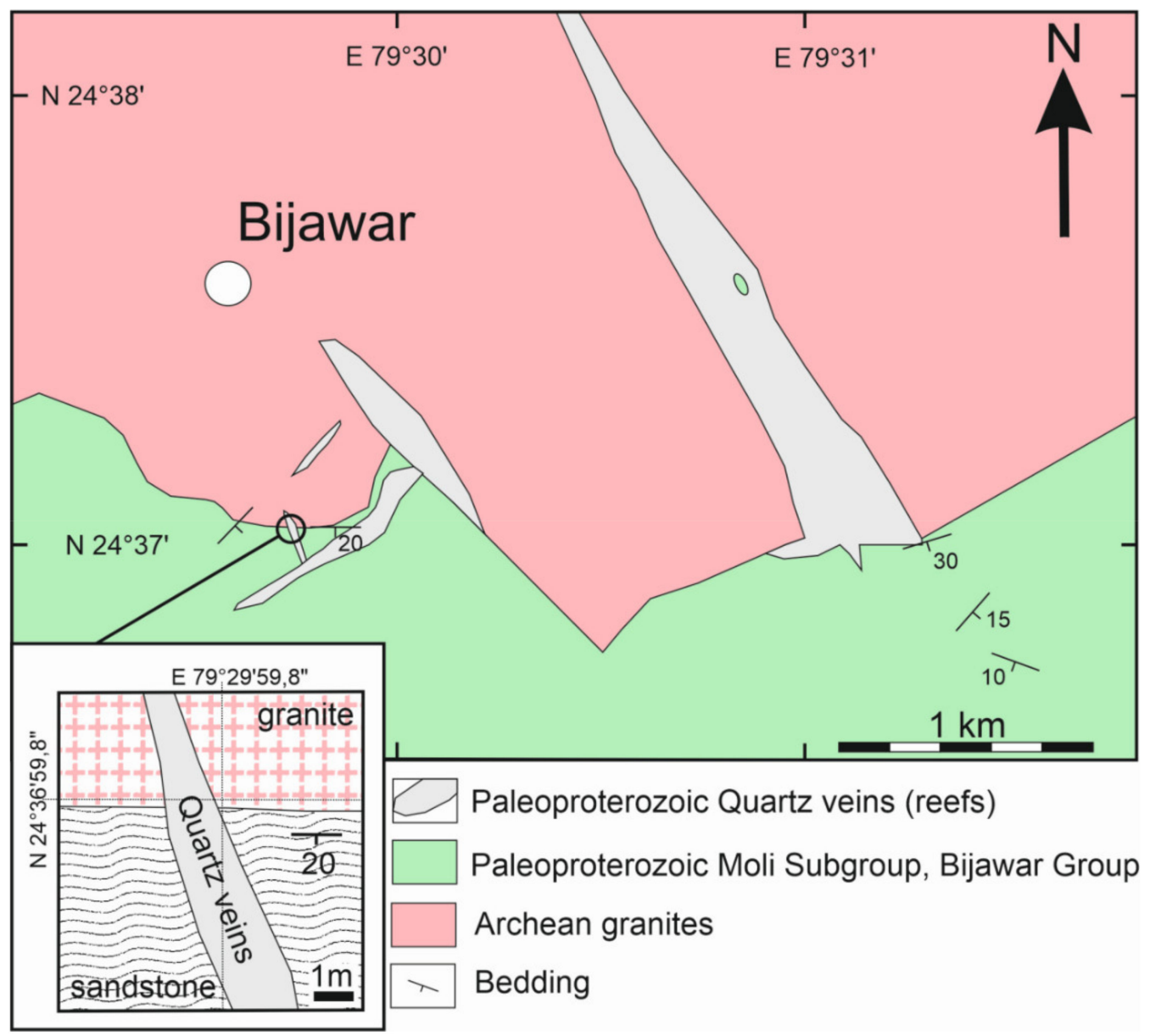

Figure 4. Geological relationship of the quartz veins with the Archean granites and sediments of the Bijawar Group on a geological map of the Bijawar area, Bundelkhand Craton.

\section{Results of Isotope Dating}

Twenty relatively small $(50-200 \mu \mathrm{m})$ zircon grains were extracted from the reddishmilky quartz sample taken in the Babina area (Figure 3). Zircon grains formed prismatic crystals with an elongation ratio of 1 to 2.5 (Figure 5). The 11 zircon grains were used for isotope dating on a SHRIMP-II ion probe at VSEGEI, St. Petersburg, Russia, and all 14 analytical spots are listed for detailed isotopic studies in this article (Table 1).

The separated zircon grains were divided into two morphological groups: homogeneous zircon grains (Figure $5 \mathrm{a}, \mathrm{b}$ ) and zircon grains with cores (Figure $5 \mathrm{c}$ ). The homogeneous zircon grains were subdivided into two varieties: (1) zircon grains with a well-defined oscillation zoning and fine to coarse and contrasting color on CL images (Figure 5a). In addition, zircon grains of this group are poor in $\mathrm{U}(108-542 \mathrm{ppm})$ and display a relatively high Th/U ratio of $0.32-1.05$ (Table 1). All the above features are typical of magmatic zircon grains [50,51]. Based on ${ }^{207} \mathrm{~Pb} /{ }^{206} \mathrm{~Pb}$ age (Table 1), zircon grains of these varieties were designed into three age clusters: $\mathrm{Zrn}_{1}$ (2856 $\pm 12 \mathrm{Ma}$ ), Zrn (ca. 2679-2699 Ma), Zrn (2416-2563 Ma) (Figures 5a and 6a). (2) second variety of zircon grains of this group display no zoning, shows a dark color on CL images (Figure 5b), is rich in U (1193-1478 ppm), and exhibits a high Th/U ratio (0.31-0.33) (Table 1). These zircon grains may be interpreted as hydrothermal originated. Based on ${ }^{207} \mathrm{~Pb} /{ }^{206} \mathrm{~Pb}$ age, zircon grains $\left(\mathrm{Zrn}_{4}\right)$ of varying age were identified from $1874 \pm 60$ to $1670 \pm 59$ Ma (Table 1; Figure 6a). 
Table 1. U-Th-Pb isotope (SHRIMP-II) data for zircon grains from Quartz vein (BA15-2/2).

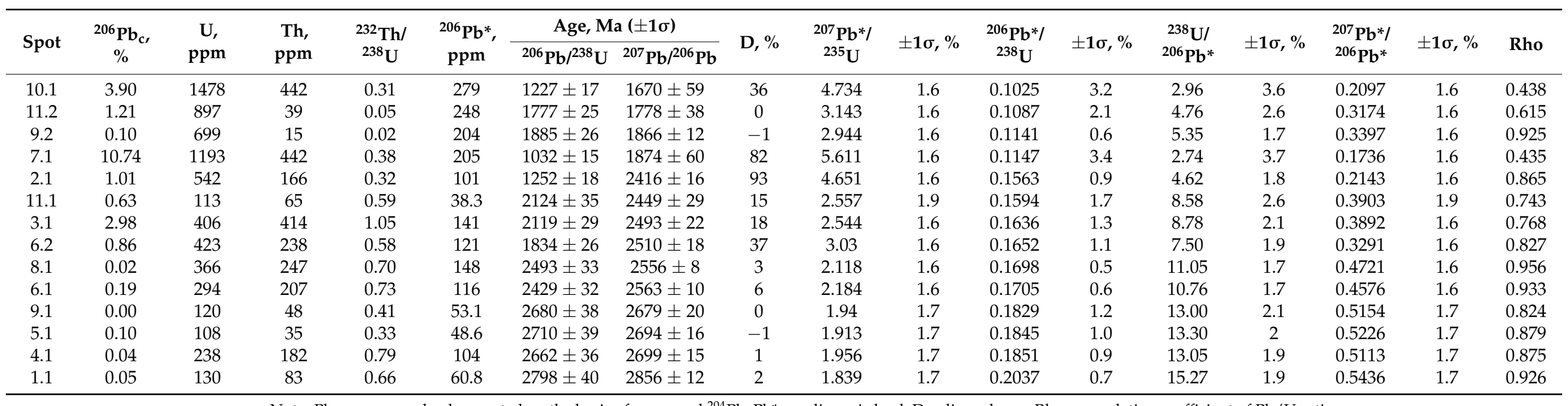

Note: $\mathrm{Pbc}$-common lead corrected on the basis of measured ${ }^{204} \mathrm{~Pb} ; \mathrm{Pb}^{*}$ — radiogenic lead; $\mathrm{D}$-discordance; Rho—correlation coefficient of $\mathrm{Pb} / \mathrm{U}$ ratios. 

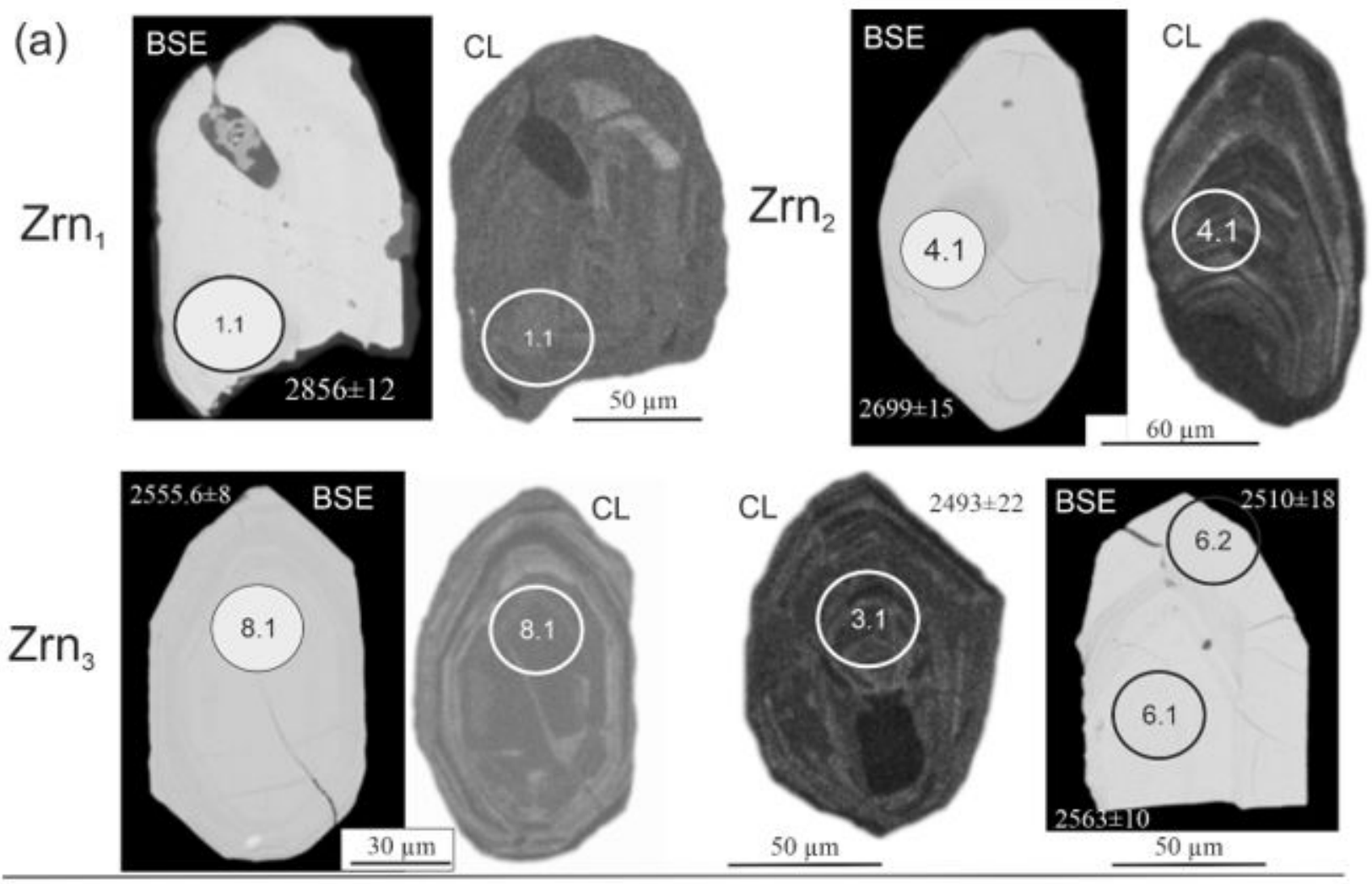

(b)
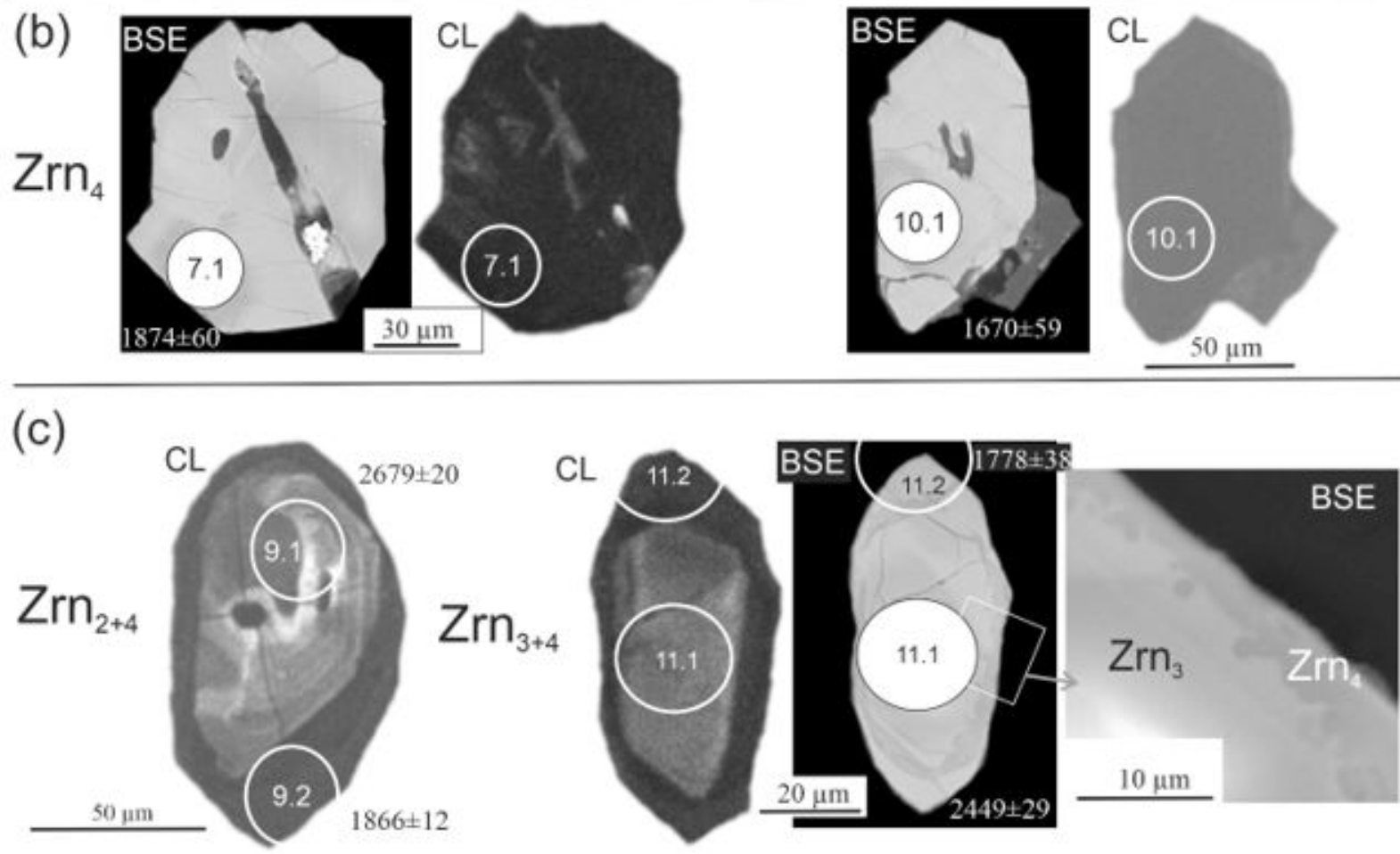

Figure 5. Back-scattered electron (BSE) and Cathodoluminescence (CL) images of (a,b) homogeneous and (c) with cores zircon grains from Quartz vein BA15-2/2; with Archean $\left(\mathrm{Zrn}_{1}, \mathrm{Zrn}_{2}, \mathrm{Zrn}_{3}\right)$ and Paleoproterozoic $\left(\mathrm{Zrn}_{4}\right){ }^{207} \mathrm{~Pb} /{ }^{206} \mathrm{~Pb}$ age; circles indicate the SHRIMP spot locations and are labeled with the spot number and the approximate spot ${ }^{207} \mathrm{~Pb} /{ }^{206} \mathrm{~Pb}$ age (in Ma) (Table 1). 
(a)

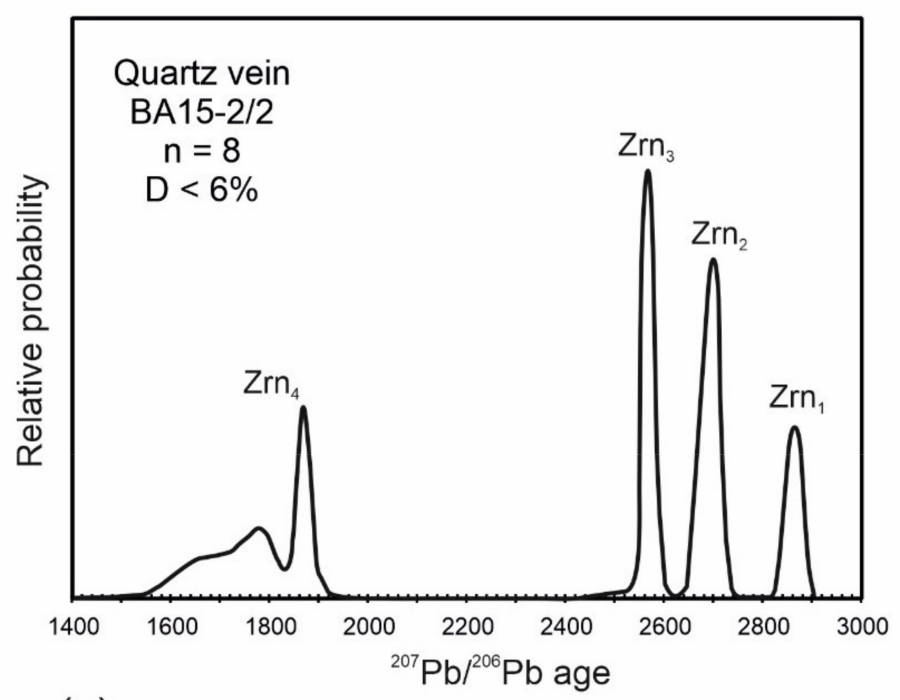

(c)

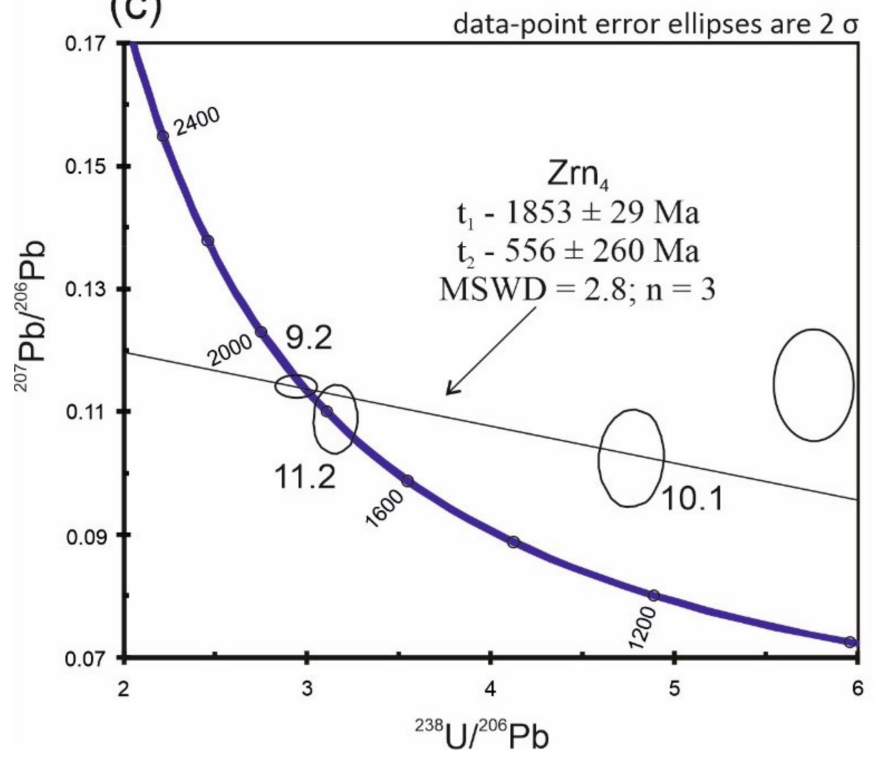

(b)

data-point error ellipses are $2 \sigma$

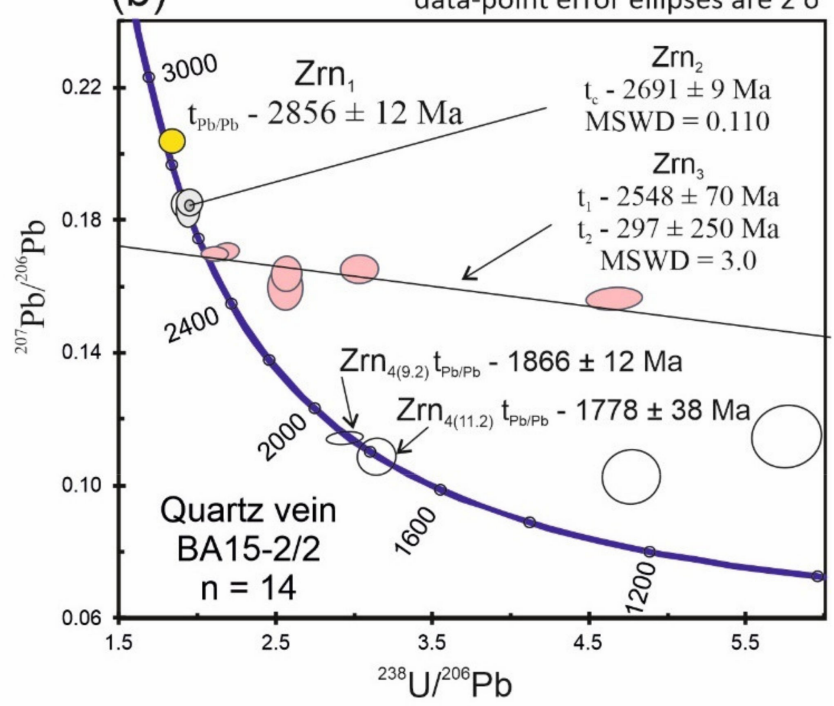

Figure 6. (a) Probability density plot (n—number of analytical spots; D—discordance), and (b,c) TeraWasserburg plots for zircon grains from Quartz vein BA15-2/2; data-point error ellipses and symbols are $2 \sigma$. ( $t_{1}$ - the upper intersection of Discordia age; $t_{2}$ - the lower intersection of the Discordia age; $\mathrm{t}_{\mathrm{c}}$-Concordia age; $\mathrm{t}_{\mathrm{Pb} / \mathrm{Pb}}-{ }^{207} \mathrm{~Pb} /{ }^{206} \mathrm{~Pb}$ age).

A second morphological group of zircon grains is represented by zircon grains with xenocrystic cores (Figure 5c). The cores of these zircon grains display oscillation zoning similar to the zoning in $\mathrm{Zrn}_{1-3}$ grains. Their ${ }^{207} \mathrm{~Pb} /{ }^{206} \mathrm{~Pb}$ ages (2679 \pm 20 and $\left.2449 \pm 29 \mathrm{Ma}\right)$ (Table 1; Figure 5c) are also correlated with the zircon grains of this cluster. Rims in this group consist of zircon grains with a homogeneous structure and are dark on CL images (Figure 5c). According to these characteristics, they are similar to $\mathrm{Zrn}_{4}$ grains of group 1. This similarity increases when considering the ${ }^{207} \mathrm{~Pb} /{ }^{206} \mathrm{~Pb}$ age of the rims: $1866 \pm 12 \mathrm{Ma}$ (analytical spot 9.2) and $1778 \pm 38 \mathrm{Ma}$ (analytical spot 11.2) (Table 1, Figure 5c). Interestingly, the boundaries between the rims and cores display a corrosion origin (Figure 5c), which indicates the hydrothermal origin of this zircon generation.

Thus, the zircon grains sampled can be classified into four groups differing in structure and age. 
(1) The oldest zircon grain ( $\mathrm{Zrn}_{1}$-analytical spot 1.1) from quartz vein was recorded $\left({ }^{207} \mathrm{~Pb} /{ }^{206} \mathrm{~Pb}\right.$ age $)$ at $2856 \pm 12 \mathrm{Ma}$ (Table 1 , Figure $\left.6 \mathrm{a}, \mathrm{b}\right)$. Considering its structure and composition $(\mathrm{Th} / \mathrm{U}=0.66)$, it is interpreted as a xenocrystic zircon grain of magmatic origin.

(2) A zircon group $\left(\mathrm{Zrn}_{2}\right)$ consisting of analytical spots 4.1, 5.1, and 9.1 (Table 1) is also of magmatic origin and is interpreted as xenocrystic zircon. Their $\mathrm{U}-\mathrm{Pb}$ Concordia age is $2691 \pm 9$ Ma (Figure 6b).

(3) The largest group of xenocrystic zircon grains consisting of analytical spots 2.1, $3.1,6.1,6.2,8.1$, and 11.1 (Table 1 ) has a ${ }^{207} \mathrm{~Pb} /{ }^{206} \mathrm{~Pb}$ age of about 2.56-2.42 Ga (Figure 6a). All the analytical points $(2.1,3.1,6.1,6.2,8.1,11.1)$ of the zircon grains are formed on the $\mathrm{U}-\mathrm{Pb}$ Tera-Wasserburg plot with a Concordia single isochron line (Figure $6 \mathrm{~b}$ ). The U-Pb age of this group of zircon grains estimated from the upper intersection with Discordia is $2548 \pm 70 \mathrm{Ma}$ and Lower intercept at $297 \pm 250 \mathrm{Ma}$, MSWD $=3.0$. This age is consistent with the magmatic stage of zircon grains formation. It should be noted that one of the cores (spot 11.1) consists of the zircon grain of this group.

(4) Zircon grains of group $4\left(\mathrm{Zrn}_{4}\right)$ form both an individual grain (Figure $5 \mathrm{~b}$, spot $7.1,10.1$ ) and a rims (Figure 5c, spot 9.2, 11.2) occur around a Neoarchean (2.7-2.5 Ga) xenocrystic core (Figure $5 \mathrm{c}$ ). The $\mathrm{U}-\mathrm{Pb}$ age of this group of zircon grains (analytical spots 9.2, 11.2, 10.1; without spot 7.1, which have very high discordance (83\%)), estimated from the upper intersection with Concordia at $1853 \pm 29 \mathrm{Ma}$ (Figure 6c). This age should be a rough estimate of the age of the hydrothermal event. However, the ${ }^{207} \mathrm{~Pb} /{ }^{206} \mathrm{~Pb}$ age of the most concordian ( $\mathrm{D}=0,-1 \%$, Table 1) zircons from rims (analytical spots 9.2 and 11.2) are $1866 \pm 12$ and $1778 \pm 38 \mathrm{Ma}$ acceptable (Figure 6b, Table 1). This zircon grains have identical morphological (homogeneous structure, rims) and geochemical (rich in U-700-900 ppm, low in Th-15-39 ppm, low Th/U-0.02-0.05) characteristics and therefore, cannot considered for two different events. The ${ }^{207} \mathrm{~Pb} /{ }^{206} \mathrm{~Pb}$ age $1866 \pm 12 \mathrm{Ma}$ can be interpreted as the most precise crystallization age of hydrothermal-metamorphic zircon $\mathrm{Zrn}_{4}$.

\section{Discussion}

The geochronological study of zircon grains from a quartz vein has shown that the samples consist of three groups of 2.86, 2.69, and $2.5 \mathrm{Ga}$ xenocrystic zircon grains and rims of $1.87 \mathrm{Ga}$ hydrothermal-metamorphic zircon. The obtained $\mathrm{U}-\mathrm{Th}-\mathrm{Pb}$ isotope data do not allow to mark out two hydrothermal-metamorphic events surely as it follows from petrographic data. If to consider the last, then it is possible to assume with a big share of uncertainty that there were two phases of quartz veins formation: $1866 \pm 12$ and $1778 \pm 38 \mathrm{Ma}$. However, this bold speculation demands justification by a fuller set of geochronological data.

The ages of the xenocrystic zircon grains are consistent with the fact that the quartz vein, from which a geochronological sample was taken, cuts the granite-greenstone complex of the Central Bundelkhand terrain. In the surrounding area, Neoarchean 2.57-2.48 Ga K-granites is dominated; and $2542 \mathrm{Ma}$ felsic volcanic occur as well $[17,18]$. These rocks are the source of the most representative group of zircon grains. Neoarchean (2.67 Ga) TTG [24] could be host rocks for Neoarchean $(2.69 \pm 0.02 \mathrm{Ga})$ xenocrystic zircon grains in the veins. Mesoarchean $(2.86 \mathrm{Ga})$ zircon grains, the rarest of xenocrystic grains, could have been trapped from rocks simultaneous with Mesoarchean magmatism [22].

The ages of the quartz veins obtained are consistent with geological results, which indicate that the quartz veins cut Paleoproterozoic sediments of the Moli Subgroup of the Bijawar Group (Figure 4) and are overlain by Kaimur Group conglomerates (basal Upper Vindhyan) (Figure 2f). The Bijawar Group formed 2150-1800 Ma ago. Hence, the quartz veins derived $1.87 \mathrm{Ga}$ ago intruded into both the craton basement and an overlain Bijawar sediments. Veins in the central zone of the craton formed at a depth of at least $10 \mathrm{~km}$, because prehnite-pumpellyite-facies metamorphism associated with quartz veins took place at $\mathrm{P}=3-5 \mathrm{kbar}$ and $\mathrm{T}=150-250{ }^{\circ} \mathrm{C}[27,28]$. This means that the $\sim 10 \mathrm{~km}$ thick crust 
was eroded, and deep-seated rocks were exposed before the formation of conglomerates or breccia (Figure 2f).

In the Paleoproterozoic (2.1-1.9 Ga), the Bundelkhand Craton seems to have been affected by a mantle plume. Rift-related basins formed in this period. Two of them were in the northern (Gwalior) and southern (Bijawar) zones of the craton (fragments of these basins have been preserved) (Figure 7a).

(a) ca. $2.0-1.9 \mathrm{Ga}$

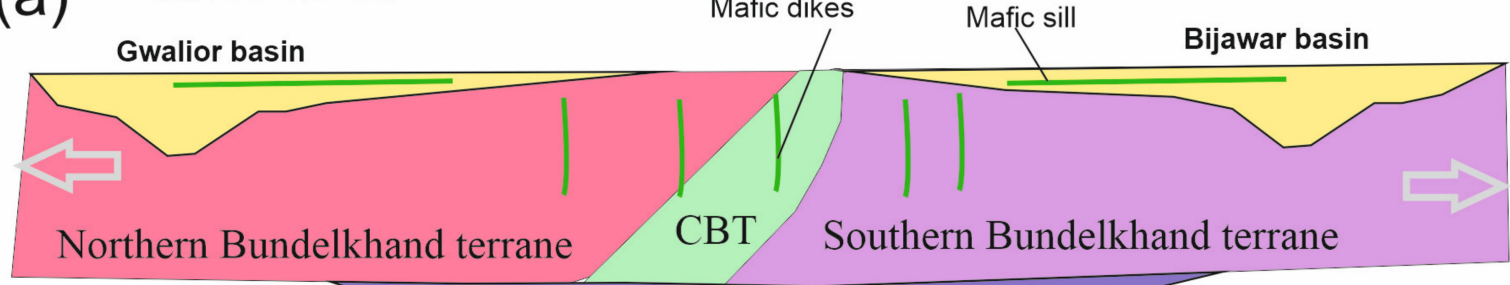

Underplating root

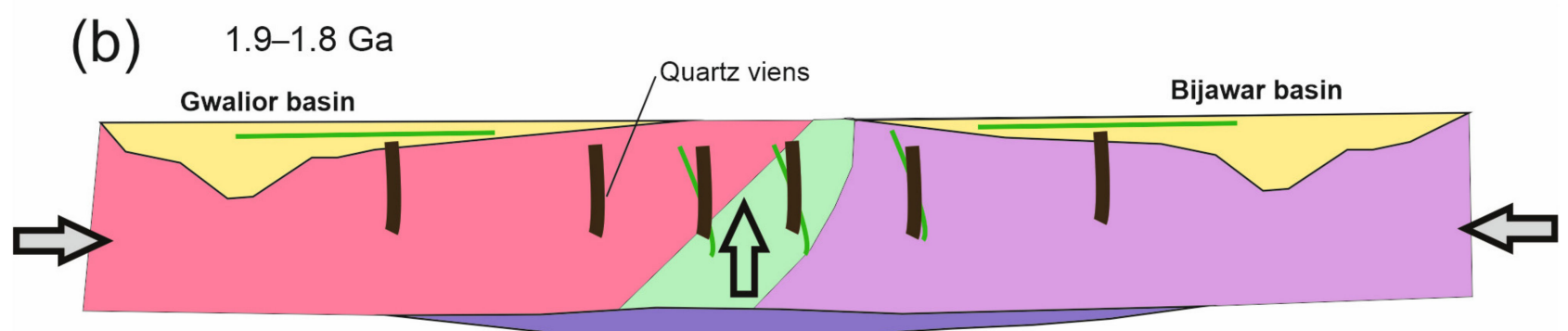

(c)

ca. $1.65 \mathrm{Ga}$

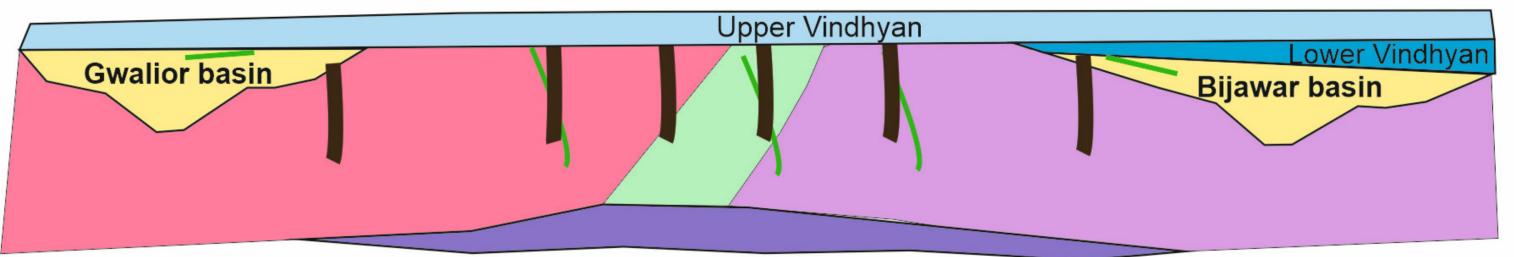

Figure 7. Schematic geodynamic model of the ca. 2.0-1.65 Ga crustal evolution of the Bundelkhand Craton and the formation of giant quartz veins (according to [19,28,32,52]). (a) 2.0-1.9 Ga Gwalior and Bijawar rift basins with sills and mafic dikes formed due to a mantle plume; (b) 1.9-1.8 Ga quartz veins formation associated with the uplifting of the Bundelkhand Craton triggered by compression caused by collision processes on one side and plume activity on the other; (c) 1.65 Ga Upper Vindhyan Supergroup deposition overlaps the Archean rocks of the Bundelkhand Craton and the Paleoproterozoic sediments of the Bijawar/Gwalior Group. CBT-Central Bundelkhand terrane.

Swarms of Paleoproterozoic (2.1 and 1.99 Ga) NW-SE - oriented mafic dikes and sills in the Gwalior and Bijawar rift basins formed due to a mantle plume. The basic intrusion seems to have been accompanied by the underplating of mafic rocks at the base of the crust, as shown in some models [53]. Mafic dike swarms in Paleoproterozoic (2.1-2.0, and 1.9-1.8 Ga) Large Igneous Provinces (LIP) are widespread in the Columbia Supercontinent with the Bundelkhand Craton as part of it [54,55]. 2.1-1.9 Ga igneous complexes of LIP formed in the different parts of the supercontinent. In addition to the craton discussed, they are well-known in the Karelian, Superior, North Atlantic, Wyoming, North China, Kaapvaal, and West African Cratons $[55,56]$, but the subsequent formation of quartz vein swarms has only been reported from the Bundelkhand Craton. Mafic dike swarms and/or sills formed simultaneously with the quartz vein swarm of the Bundelkhand Craton within the supercontinent. The mafic dike swarms and/or sills were encountered in North China, 
Amazonian, São Francisco, Rio de la Plata, Baltica, West African, Siberian, Superior, Slave, Zimbabwe, Kaapvaal, Dharwar, and Bastar Cratons [55,57,58], but there are not in the Bundelkhand Craton. Special attention should be given to the fact that ca. $1.88 \mathrm{Ga}$ ago LIP, traces of which were found in North China (Laiwu and Taishan Dykes, Xiong'er rift), Superior (Molsen Dykes, Clearwater sills), Dharwar (Dharmapuri Dykes, Tadpatri sill), and Bastar Cratons (dolerite dykes), began to form under the influence of the plume [54,55]. The center of this LIP on the Columbia Supercontinent was located about $800 \mathrm{~km} \mathrm{SE} \mathrm{(in}$ the modern coordinate system) of the Bundelkhand Craton. In the Early Paleoproterozoic (1.95-1.85 Ga), lying NW of it was the western margin of the Columbia Supercontinent, where subduction-collision processes gave rise to a new continental crust $[3,54,59]$.

Thus, the formation of the giant quartz vein swarm in the Bundelkhand Craton (Figure $\mathrm{7b}$ ) began to form at $1.87 \mathrm{Ga}$, when the center of an active mantle plume was to the southeast, and a collision zone to the northwest. This combination could have been produced by uplifting, extension, metamorphism, and intense hydrothermal processes. As a result, a NE-SW-trending swarm of hydrothermal quartz veins began to be formed in the earth's crust of the central Bundelkhand Craton at about $1.87 \mathrm{Ga}$.

It is important to note that the U-Pb ages of 1.9-1.85 Ga obtained for zircon grains play the leading role among detrital zircon grains in the upper portion of the Gwalior Group sequence, but this age group is not present in the lower portion of the sequence, while a Neoarchean (ca. 2.5-2.6 Ga) group of zircon grains prevail [32]. The proportion of 1.9-1.8 Ga xenocrystic zircon grains in Lower and Upper Vindhyan Supergroup sediments is also abundant [32]. This indicates that during the formation of the Vindhyan basin (Figure 7c), its source area was occupied or filled with an abundance of metamorphosed (1.9-1.8 Ga ago) rocks when the quartz veins were forming.

\section{Main Conclusions}

1. New geological data proved that the giant quartz veins of the Bundelkhand Craton cut the Paleoproterozoic (2150-1800 Ma) sediments of the Bijawar Group and are overlain by Proterozoic (1670-1030 Ma) sediments at the base of the Upper Vindhyan Supergroup. Therefore, the relative geological age of the quartz veins can thus be inferred in between.

2. U-Th-Pb dating of zircon grains from the quartz vein is indicate starting hydrothermal event for their formation at $1866 \pm 12 \mathrm{Ma}$. This data is consistent with the relative geological age of the quartz veins as discussed above.

3. The formation of the swarm of giant quartz veins was associated with the uplifting of the Bundelkhand Craton during 1.9-1.8 Ga ago, which seems to have been triggered by compression caused by collision processes at the western flank of the Columbia Supercontinent on one side and plume activity on the other.

Author Contributions: Conceptualization, A.I.S. and V.K.S.; methodology, A.I.S.; validation, A.I.S.; investigation, A.I.S. and V.K.S.; resources, A.I.S.; data curation, A.I.S.; writing-original draft preparation A.I.S.; writing-review and editing, A.I.S. and V.K.S.; visualization, A.I.S. and V.K.S.; supervision, A.I.S.; project administration, A.I.S.; funding acquisition, A.I.S. All authors have read and agreed to the published version of the manuscript.

Funding: The paper has been partly prepared in the framework of research projects of the Karelian Research Center of the RAS (\#AAAA-A18-118020290085-4).

Data Availability Statement: We accessed images on 11 April 2018 from site Google Earth https: / / earth.google.com/web/@21.18665933,77.59897369,362.62522031a,2977943.64498407d,35y,-0h,0t,0r.

Acknowledgments: We wish to thank Nikita S. Yeremin for compiling a geological map of a swarm of giant quartz veins in the Bundelkhand Craton under the supervision of A.I. Slabunov. The authors are thankful to Victor V. Balagansky for consultation on structural geology and to Tatiana V. Kaulina for consultation on geochronology. The work was carried out under MOU between Bundelkhand University, Jhansi, India, and the Institute of Geology, Karelian Research Centre, RAS, Petrozavodsk, 
Russia. Thanks to the two anonymous reviewers and editors for their insightful comments and suggestions that greatly helped improve this article.

Conflicts of Interest: The authors declare no conflict of interest.

\section{References}

1. Bons, P.D.; Elburg, M.A.; Gomez-Rivas, E. A review of the formation of tectonic veins and their microstructures. J. Struct. Geol. 2012, 43, 33-62. [CrossRef]

2. Pati, J.K.; Patel, S.C.; Pruseth, K.L.; Malviya, V.P.; Arima, M.; Raju, S.; Pati, P.; Prakash, K. Geology and geochemistry of giant quartz veins from the Bundelkhand Craton, central India and their implications. J. Earth Syst. Sci. 2007, 116, 497-510. [CrossRef]

3. Ramakrishnan, M.; Vaidyanadhan, R. Geology of India; Geological Society of India Publications: Bangalore, India, 2010; Volume 1, 556p.

4. Pati, J.K.; Raju, S.; Pruseth, K.L.; Magngain, V.D.; Shankar, R. Gold mineralization in parts of Bundelkhand Granitoid Complex (BGC). J. Geol. Soc. India 1997, 50, 601-606.

5. Pati, J.K. Evolution of Bundelkhand Craton. Episodes 2020, 43, 69-87. [CrossRef]

6. Roy, A.B.; Purohit, R. Indian Shield: Precambrian Evolution and Phanerozoic Reconstitution; Elsevier Inc.: Cambridge, MA, USA, 2018.

7. Jain, A.K.; Banerjee, D.M.; Kale, V.S. Tectonics of the Indian Subcontinent; Springer Nature: Cham, Switzerland, 2020; 576p.

8. $\quad$ Singh, P.K.; Verma, S.K.; Singh, V.K.; Moreno, J.A.; Oliveira, E.P.; Li, X.; Malviya, V.P.; Prakash, D. Geochronology and petrogenesis of the TTG gneisses and granitoids from the Central Bundelkhand granite-greenstone terrane, Bundelkhand Craton, India: Implications for Archean crustal evolution and cratonization. Precambrian Res. 2021, 359, 106210. [CrossRef]

9. Joshi, K.B.; Bhattacharjee, J.; Rai GHalla, J.; Kurhilla, M.; Heilimo, E.; Ahmad, T.; Whitehouse, M. The diversification of granitoids and plate tectonic implications at the Archaean-Proterozoic boundary in the Bundelkhand Craton, Central India. In Crust-Mantle Interactions and Granitoid Diversification: Insights from Archaean Cratons; Special Publications 449; Halla, J., Whitehouse, M.J., Ahmad, T., Bagai, Z., Eds.; Geological Society: London, UK, 2017; pp. 123-157.

10. Kaur, P.; Zeh, A.; Chaudhri, N.; Eliyas, N. Unravelling the record of Archaean crustal evolution of the Bundelkhand Craton, northern India using $\mathrm{U}-\mathrm{Pb}$ zircon-monazite ages, Lu-Hf isotope systematics, and whole-rock geochemistry of granitoids. Precambrian Res. 2016, 281, 384-413. [CrossRef]

11. Kaur, P.; Zeh, A.; Chaudhri, N. Characterization and U-Pb-Hf isotope record of the 3.55Ga felsic crust from the Bundelkhand Craton, northern India. Precambrian Res. 2014, 255, 236-244. [CrossRef]

12. Malviya, V.P.; Arima, M.; Pati, J.K.; Kaneko, Y. Petrology and geochemistry of metamorphosed basaltic pillow lava and basaltic komatiite in the Mauranipur area: Subduction related volcanism in the Archean Bundelkhand craton, Central India. J. Miner. Petrol. Sci. 2006, 101, 199-217. [CrossRef]

13. Mondal, M.E.A.; Goswami, J.N.; Deomurari, M.P.; Sharma, K.K. Ion microprobe 207Pb/206Pb ages of zircons from the Bundelkhand massif, northern India: Implications for crustal evolution of the Bundelkhand-Aravalli protocontinent. Precambrian Res. 2002, 117, 85-100. [CrossRef]

14. Saha, L.; Frei, D.; Gerdes, A.; Pati, J.K.; Sarkar, S.; Patole, V.; Bhandari, A.; Nasipuri, P. Crustal geodynamics from the Archaean Bundelkhand Craton, India: Constraints from zircon U-Pb-Hf isotope studies. Geol. Mag. 2016, 153, 79-192. [CrossRef]

15. Singh, V.K.; Slabunov, A. The Central Bundelkhand Archaean greenstone complex, Bundelkhand Craton, Central India: Geology, composition, and geochronology of supracrustal rocks. Int. Geol. Rev. 2015, 57, 1349-1364. [CrossRef]

16. Singh, P.K.; Verma, S.K.; Moreno, J.A.; Singh, V.K.; Malviya, P.K.; Oliveira, E.P.; Mishra, S.; Arima, M. Geochemistry and Sm-Nd isotope systematics of metabasalts from the Babina and Mauranipur greenstone belts, Bundelkhand craton: Implications for tectonic setting and Paleoarchean mantle evolution. Lithos 2019, 330-331, 90-107. [CrossRef]

17. Singh, P.K.; Verma, S.K.; Singh, V.K.; Moreno, J.A.; Oliveira, E.P.; Mehta, P. Geochemistry and petrogenesis of sanukitoids and high-K anatectic granites from the Bundelkhand craton: Implications for the late-Archean crustal evolution. J. Asian Earth Sci. 2019, 174, 263-282. [CrossRef]

18. Singh, V.K.; Verma, S.K.; Singh, P.K.; Slabunov, A.I.; Mishra, S.; Chaudhary, N. Archean crustal evolution of the Bundelkhand Craton: Evidence from granitoid magmatism. In Archean Granitoids of India: Windows into Early Earth Tectonics; Special Publications 489; The Geological Society: London, UK, 2020; pp. 235-259.

19. Singh, V.K.; Slabunov, A.I.; Nesterova, N.S.; Singh, M.M.; Bhatt, S.C. Tectonostratigraphic terranes of the Bundelkhand Craton (Indian Shield). In Geological and Geo-Environmental Processes on Earth; Shandilya, A.K., Singh, V.K., Bhatt, S.C., Dubey, C.S., Eds.; Springer Natural Hazards: Singapore, 2021; pp. 155-164.

20. Slabunov, A.; Singh, V.K.; Joshi, K.B.; Li, X. Paleoarchean zircons from quartzite of South Bundelkhand Supracrustal Complex: Origin and implications for crustal evolution in Bundelkhand Craton, Central India. Curr. Sci. 2017, 112, 794-801. [CrossRef]

21. Slabunov, A.; Egorova, S.; Singh, V.K.; Svetov, S.; Kumar, S. Archean mafic-ultramafic Ikauna layered intrusion, Bundelkhand craton, India: Petrography and geochemistry. Arch. Anthropol. Open Acc. 2018, 3 (Suppl. 2), 49-55.

22. Slabunov, A.I.; Singh, V.K. Meso-Neoarchaean crustal evolution of the Bundelkhand Craton, Indian Shield: New data from greenstone belts. Int. Geol. Rev. 2019, 61, 1409-1428. [CrossRef]

23. Slabunov, A.I.; Singh, V.K. The new tectonic division of the Bundelkhand Craton Indian Shield. In Transactions of A. Fersman Scientific Session of Geological Institute, Kola Research Centre; RAS: Apatity, Russia, 2019; Volume 16, pp. 521-524. 
24. Verma, S.K.; Verma, S.P.; Oliveira, E.P.; Singh, V.K.; More, J.A. LA-SF-ICP-MS zircon U-Pb geochronology of granitic rocks from the central Bundelkhand greenstone complex, Bundelkhand craton, India. J. Asian Earth Sci. 2016, 118, 125-137. [CrossRef]

25. Saha, L.; Pant, N.C.; Pati, J.K.; Upadhyay, D.; Berndt, J.; Bhattacharya, A.; Satynarayanan, M. Neoarchean high-pressure margarite-phengitic muscovite-chlorite corona mantled corundum in quartz-free high-Mg, $\mathrm{Al}$ phlogopite-chlorite schists from the Bundelkhand craton, north central India. Contrib. Miner. Petrol. 2011, 161, 511-530. [CrossRef]

26. Nasipuri, P.; Saha, L.; Hangqiang, X.; Pati, J.K.; Satyanaryanan, M.; Sarkar, S.; Bhandari, A.; Gaur, Y. Paleoarchean crustal evolution of the Bundelkhand Craton, north Central India. In Earth's Oldest Rocks, 2nd ed.; Van Kranendonk, M.J., Bennett, V.C., Hoffmann, J.E., Eds.; Elsevier: Amsterdam, The Netherlands, 2019; pp. 793-817.

27. Sibelev, O.S.; Slabunov, A.I.; Mishra, S.; Singh, V.K. Metamorphism of the Central Bundelkhand Greenstone Complex, Indian Shield: Mineral Compositions, Paragenesis's, and P-T Path. Petrology 2021, 29, 404-438. [CrossRef]

28. Sibelev, O.S.; Slabunov, A.I.; Singh, V.K.; Mishra, S. Metamorphism of the Central Bundelkhand greenstone complex of the Bundelkhand Craton., Indian Shield and its geodynamic setting. In Geological and Geo-Environmental Processes on Earth; Shandilya, A.K., Singh, V.K., Bhatt, S.C., Dubey, C.S., Eds.; Springer Natural Hazards: Singapore, 2021; pp. 143-154.

29. Radhakrishna, T.; Chandra, R.; Shrivastava, A.K.; Balasubramonian, G. Central/eastern Indian Bundelkhand and Bastar cratons in the Palaeoproterozoic supercontinental reconstructions: A palaeomagnetic perspective. Precambrian Res. 2013, $226,91-104$. [CrossRef]

30. Pradhan, V.R.; Meert, J.G.; Pandit, M.K.; Kamenov, G.; Mondal, E.A. Tectonic evolution of the Precambrian Bundelkhand craton, central India: Insights from paleomagnetic and geochronologic studies on the mafic dyke swarms. Precambrian Res. 2012, 198-199, 51-76. [CrossRef]

31. Chakraborty, P.P.; Pant, N.C.; Paul, P.P. Controls on sedimentation in Indian Palaeoproterozoic basins: Clues from the Gwalior and Bijawar basins, central India. In Precambrian Basins of India: Stratigraphic and Tectonic Context; Memoirs 43; Mazumder, R., Eriksson, P.G., Eds.; Geological Society: London, UK, 2015; pp. 67-83.

32. Colleps, C.L.; McKenzie, N.R.; Sharma, M.; Liu, H.; Gibson, T.M.; Chen, W.; Stockli, D.F. Zircon and apatite U-Pb age constraints from the Bundelkhand craton and Proterozoic strata of central India: Insights into craton stabilization and subsequent basin evolution. Precambrian Res. 2021, 362, 106286. [CrossRef]

33. Samom, J.D.; Ahmad, T.; Choudhary, A. Geochemical and Sm-Nd isotopic constraints on the petrogenesis and tectonic setting of the Proterozoic mafic magmatism of the Gwalior Basin, central India: The influence of Large Igneous Provinces on Proterozoic crustal evolution. In Large Igneous Provinces from Gondwana and Adjacent Regions; Special Publ. 463; Sensarma, S., Storey, B.C., Eds.; Geological Society: London, UK, 2018; pp. 243-268.

34. Singh, S.K.; Srivastava, R.K.; Kumar, S.; Samal, A.K. Geochemical characterization of the Paleoproterozoic (ca. 1.98-1.97) Darguwan-Surajpura mafic sills within the Bijawar basin, North-Central India: Genetic aspects and geodynamic implications. Geochemistry 2021, 81, 125689. [CrossRef]

35. Bose, P.K.; Sarkar, S.; Das, N.G.; Banerjee, S.; Mandal, A.; Chakraborty, N. Proterozoic Vindhyan Basin: Configuration and evolution (Chapter 6). In Precambrian Basins of India: Stratigraphic and Tectonic Context; Memoirs 43; Mazumder, R., Eriksson, P.G., Eds.; Geological Society: London, UK, 2015; pp. 85-102.

36. Sarangi, S.; Gopalan, K.; Kumar, S. Pb-Pb age of earliest megascopic, eukaryotic alga bearing Rohtas Formation, Vindhyan Supergroup, India: Implications for Precambrian atmospheric oxygen evolution. Precambrian Res. 2004, 132, 107-121. [CrossRef]

37. Rasmussen, B.; Bose, P.K.; Sarkar, S.; Banerjee, S.; Fletcher, I.R.; McNaughton, N.J. 1.6 Ga U-Pb zircon age for the Chorhat Sandstone, lower Vindhyan, India: Possible implications for early evolution of animals. Geology 2002, 30, 103-106. [CrossRef]

38. Bickford, M.E.; Mishra, M.; Mueller, P.A.; Kamenov, G.D.; Schieber, J.; Basu, A. U-Pb age and Hf isotopic compositions of magmatic zircons from a rhyolite flow in the Porcellanite Formation in the Vindhyan Supergroup, Son Valley (India): Implications for its tectonic significance. J. Geol. 2017, 125, 367-379. [CrossRef]

39. Mishra, M.; Bickford, M.E.; Basu, A. U-Pb age and chemical composition of an ash bed in the Chopan Porcellanite Formation, Vindhyan Supergroup, India. J. Geol. 2018, 126, 553-560. [CrossRef]

40. Gregory, L.C.; Meert, J.G.; Pradhan, V.; Pandit, M.K.; Tamrat, E.; Malone, S.J. A paleomagnetic and geochronologic study of the Majhgawan kimberlite, India: Implications for the age of the Upper Vindhyan Supergroup. Precambrian Res. 2006, 149, 65-75. [CrossRef]

41. Williams, I.S. U-Th-Pb Geochronology by Ion Microprobe. In Applications of Microanalytical Techniques to Understanding Mineralizing Processes. Reviews in Economic Geology; McKibben, M.A., Shanks, W.C., III, Ridley, W.I., Eds.; Society of Economic Geologist: Denver, CO, USA, 1998; Volume 7, pp. 1-35.

42. Larionov, A.N.; Andreichev, V.A.; Gee, D.G. The Vendian alkaline igneous suite of northern Timan: Ion microprobe U-Pb zircon ages of gabbros and syenite. Mem. Geol. Soc. Lond. 2004, 30, 69-74. [CrossRef]

43. Wiedenbeck, M.; Allé, P.; Corfu, F.; Griffin, W.L.; Meier, M.; Oberli, F.; von Quadt, A.; Roddick, J.C.; Spiegel, W. Three natural zircon standards for U-Th-Pb, Lu-Hf, trace element and REE analyses. Geostand. Newslett. 1995, 19, 1-23. [CrossRef]

44. Black, L.P.; Kamo, S.L.; Allen, C.M.; Aleinikoff, J.N.; Davis, D.W.; Korsch, R.J.; Foudoulis, C. TEMORA 1: A new zircon standart for Phanerozoic U-Pb geochronology. Chem. Geol. 2003, 200, 155-170. [CrossRef]

45. Ludwig, K.R. User's Manual for Isoplot 3.75-4.15: A Geochronological Toolkit for Microsoft Excel; Berkeley Geochronology Center Special Publication: Berkeley, CA, USA, 2012; p. 5. 
46. Yeremin, N.S. A Swarm of Giant Paleoproterozoic Quartz Veins in the Bundelkhand Craton, India: Structure Based on Cosmogeological Mapping, Petrography and Geochronology. Bachelor's Theses, Petrozavodsk State University, Petrozavodsk, Russia, 2018; 31p.

47. Steiger, R.H.; Jäger, E. Subcommission on geochronology: Convention on the use of decay constants in geo- and cosmochronology. Earth Planet. Sci. Lett. 1997, 36, 359-362. [CrossRef]

48. Stacey, J.S.; Kramers, J.D. Approximation of terrestrial lead isotope evolution by a two-stage model. Earth Planet. Sci. Lett. 1975, 26, 207-221. [CrossRef]

49. Yilmaz, T.I.; Prosser, G.; Liotta, D.; Kruhl, J.H.; Gilg, H.A. Repeated hydrothermal quartz crystallization and cataclasis in the Bavarian Pfahl shear zone (Germany). J. Struct. Geol. 2014, 68, 158-174. [CrossRef]

50. Corfu, F.; Hanchar, J.M.; Hoskin, P.W. Atlas of zircon textures. Rev. Miner. Geochem. 2003, 53, 469-500. [CrossRef]

51. Wu, Y.; Zheng, Y. Genesis of zircon and its constraints on interpretation of U-Pb age. Chin. Sci. Bull. 2004, 49, 1554-1569. [CrossRef]

52. Slabunov, A.; Singh, V.K. Giant quartz veins and rift-related basins as indicators of the Paleoproterozoic destruction of the earth crust of cratons in Northern India. In Formation and Evolution Stages of the Proterozoic Earth Crust: Stratigraphy, Metamorphism and Geodynamics, Proceedings of the 6th Russian Conference on Precambrian Geology and Geodynamics, St. Petersburg, Russia, 22-24 October 2019; pp. 16-17.

53. Thybo, H.; Artemieva, I.M. Moho and magmatic underplating in continental lithosphere. Tectonophysics 2013, 609, 605-619. [CrossRef]

54. Hou, G.; Santosh, M.; Qian, X.; Lister, G.S.; Li, J. Configuration of the Late Paleoproterozoic supercontinent Columbia: Insights from radiating mafic dyke swarms. Gondwana Res. 2008, 14, 395-409. [CrossRef]

55. Ernst, R. Large Igneous Provinces; Cambridge University Press: Cambridge, UK, 2014; 667p.

56. Stepanova, A.; Stepanov, V.; Larionov, A.; Salnikova, E.; Samsonov, A.; Azimov, P.; Egorova, S.; Babarina, I.; Larionova, Y.; Sukhanova, M.; et al. Relicts of Paleoproterozoic LIPs in the Belomorian province, eastern Fennoscandian Shield: Barcode reconstruction for a deeply eroded collisional orogeny. In Large Igneous Provinces and Their Plumbing Systems. Geological Society of London Special Publications; Srivastava, R.K., Ernst, R.E., Buchan, K.L., De Kock, M., Eds.; Geological Society of London: London, UK, 2021; p. 518.

57. Neves, S.P. Comparative geological evolution of the Borborema Province and São Francisco Craton (eastern Brazil): Decratonization and crustal reworking during West Gondwana assembly and implications for paleogeographic reconstructions. Precambrian Res. 2021, 355, 106119. [CrossRef]

58. Teixeira, W.; Hamilton, M.A.; Girard, V.A.V.; Faleiros, F.M.; Ernst, R.E. U-Pb baddeleyite ages of key dyke swarms in the Amazonian Craton (Carajás/Rio Maria and Rio Apa areas): Tectonic implications for events at 1880, $1110 \mathrm{Ma}, 535 \mathrm{Ma}$ and $200 \mathrm{Ma}$. Precambrian Res. 2019, 329, 138-155. [CrossRef]

59. Mishra, S.; Slabunov, A.I.; Svetov, S.A.; Kervinen, A.V.; Nesterova, N.S. Zircons from collisional granites, Garhwal Himalaya, NW India: U-Th-Pb age, geochemistry and protolith constraints. Minerals 2021, 11, 1071. [CrossRef] 